Butwal Campus Journal, Vol. 3, No. 1: 125-130, July 2020

Research Management Cell, Butwal Multiple Campus, Tribhuvan University, Nepal

\title{
MURRAYA KOENIGII (L.) SPRENG-CURRY LEAVES/MITHO NIM- A MIRACLE PLANT
}

\author{
Anant Gopal Singh* \\ *Associate Professor, Butwal Multiple Campus, Butwal, TU
}

Article History: Received 17 May 2020; Reviewed 16 June 2020; Revised 29 June 2020; Accepted 07 July 2020

\begin{abstract}
Murraya koenigii is a leafy medicinal as well as a green leafy aromatic shrub that belongs to the family Rutaceae of angiosperms. The various pharmacological activities of the plant have been seen such as activity on Antidiabetic, cholesterol-reducing property, antimicrobial activity, antiulcer activity, Antioxidative property, anti-diarrhea activity, anti-cancer activity with much other phagocytic activity.
\end{abstract}

Keywords: antidiarrheal - antioxidative - curry leaves - mecimer.

\section{INTRODUCTION}

Plants are one of the most important sources of medicines. Today the large numbers of drugs in use are derived from plants like morphine from Papaver somnifera, ashwagandha from Withania sominifera, quinine from Cinchona officinalis, hyoscyamine from Datura stramonium, ephedrine from Ephedra gerardiana, atropine from Atropa belladonna, and reserpine from Rauvolfia serpentina. The medicinal plants are rich in secondary metabolites and essential oils of therapeutic importance. The important advantages claimed for therapeutic uses of medicinal plants in various ailments are their easy availability, economical, effectiveness, and no side effects. Because of these advantages, medicinal plants have been widely used by traditional medical practitioners for curing various diseases in their day-to-day practice. According to a survey by the World Health Organization, more than 80 percent of the 
world's population relies on traditional herbal medicine for their primary healthcare (Ekor, 2013).

Murraya koenigii known as curry leaf or mitho neem, mecimer, mecia sag in Nepali dialects, is an aromatic shrub or small tree up to $6 \mathrm{~m}$ in height, belonging to the family Rutaceae of angiosperms. It is a native of Nepal, India, Sri Lanka, and other South Asian countries. Of the 14 global species belonging to the genus Murraya, only two species are available in Nepal namely Murraya koenigii (L.) Spreng., and Murraya paniculata (L.) Jack (Press et al., 2000). Of the two, the Murraya koenigii is more popular due to its large spectrum of medicinal properties and also because of the use of its leaves for centuries as a natural flavouring agent in various curries and food items.

Curry leaves are a popular leaf spice used in very small quantities for their distinct aroma and their ability to improve digestion. Herbal and natural products of folk medicine have been used for centuries in every culture throughout the world. The important advantages claimed for therapeutic uses of medicinal plants in various ailments are their safety besides being economical, effective, and easy availability.

\section{MATERIALS AND METHODS}

Literature data was collected from very well reputed scientific databases. The search was conducted using Murraya koenigii or Curry leaves as a keyword. The review title was also used to access relevant articles.

\section{LITERATURE REVIEW}

The present review incorporates the origin and distribution of Murraya koenigii, its ethnobotany and various pharmacological scientific data on remedial statement of different parts of plant specially leaf formulations.

\section{Morphological characters}

A small spreading shrub about 2-6 $\mathrm{m}$ high; the main stem dark green to brownish with numerous dots on it; its grey colour bark can be peeled off longitudinally, exposing the white wood underneath; the diameter of the main stem is $16 \mathrm{~cm}$. Leaves exstipulate, bipinnately 
compound, 15-30 cm long, each bearing 11-25 leaflets having reticulate venation; leaflets lanceolate.

Flowers bisexual, white funnel-shaped, sweetly scented, pedicellate, complete, ebracteate, regular, actinomorphic, pentamerous, hypogynous, the inflorescence is terminal cyme, each bearing 60-90 flowers. Calyx 5-lobed, persistent, and green. Corolla white, polypetalous, androecium polyandrous with 10 stamens. Fruits that occur in cluster form vary from 32-80 in numbers (Prabhu \& Tamilanban, 2012). The fruits are in ovoid or sub-globose and small in size, fully ripe fruits are purple-black with a very shiny surface. Each fruit has a single spinach green seed. Propagation of this plant is done by seeds, which germinate freely under partial shade. The flowering and fruiting time of this plant is February to April. This plant is easily available in the subtropical and tropical forests of Nepal.

\section{Taxonomic status}

(1) Kingdom- Plantae (2) Sub-kingdom- Tracheobionata (3) Super-division- Spermatophyta (4) Division- Magnoliophyta (5) Class- Magnoliopsida (6) Subclass- Rosidae (7) FamilyRutaceae (8) Genus- Murraya (9) Species- M. koenigii (L.) Spreng.

The English name of this plant is Indian Curry leaf. Ethnic names of Murraya koenigii in Nepal are Mecimer, Meciya sag, Mitho nim, etc. The Sanskrit name of this plant is Girinimba/Suravi.

\section{Medicinal importance}

Green leaves are eaten raw for the cure of dysentery, diarrhea, and for checking to vomit (Dhami, 2008; Acharya and Acharya, 2009). Leaves and roots are also used traditionally as an anthelmintic, analgesic, curing piles, inflammation, itching and are useful in leucoderma and blood disorders. This plant has been reported to have antioxidative, antimicrobial, antibacterial, antiulcer, and cholesterol-reducing activities (Shaikh et al., 2020).

The oil extracted from the seed is used externally for bruises, eruptions, in the soap and perfume industry (Prajapati et al., 2003). Oil extracted from seed applying on the affected area to cure dermatological disorders such as pimples, athlete's foot, ringworm, itches, acne, boils and, septic wounds and burns (Dasgupta et al., 2003). The essential oil of Murraya koenigii is utilized in the soap and cosmetic industry for aromatherapy (Chowdhury and Chowdhury 1969). The richness of vitamin A and calcium in Curry leaf oil is used for 
strengthening the bone, osteoporosis, calcium deficiency, and radiotherapy and chemotherapy treatments of cancer (Srinivasan 2005).

The essential oil extracted from leaves of M. koenigii showed antibacterial effect against Bacillus subtilis, Staphylococcus aureus (Goutam \& Purohit 1974),Escherichia coli, Salmonella typhi (Tiwari \& Talreja, 2020) and antifungal activity against Aspergillus niger, A. fumigates and Microsporum gypseum ( Kishore et al., 1982) etc. Fresh leaves, dried leaf powder, and essential oil of curry leaf is widely used as flavouring soups, curries, fish, meat dishes, egg dishes, traditional curry powder blends, seasoning, and ready to use other food preparations (Fiebig et al., 1985). Curry leaves are boiled with coconut oil till they are reduced to a blanked residue which is then used as an excellent hair tonic for retaining natural hair tone and stimulating hair growth (Saini \& Reddy, 2015).

Leaves are roasted and used in vegetables for good fragrance and taste (Singh et al., 2012). Leaf paste applied externally on cuts and wounds to destroy pathogenic organisms (Singh et al., 2012). Entire plants are used as an insect repellent (Uprety et al., 2010). Leaves of this plant are used as hepatotonic and decoction of leaves is given in snake bite (Singh, 2014). Leaves are used to cure stomach disorders and vomiting (Singh, 2015). Leaves and roots care for piles and blood disorders. The whole plant used as tonic and stomachic, bark, and roots are stimulants (Paudel et al., 2018). Different parts of this medicinally important plant are used for various purposes by ethnic communities of Nepal are:

- Leaves, roots, bark, and fruits are used for flavouring soups.

- Fresh leaves are used in curries for flavouring.

- Branches are used as brushes for clean teeth which protect dental caries caused by bacteria.

- Powder of dry leaf in common dishes increases the sources of micronutrients.

- Roots used as stimulant and leaves used to cure dysentery and vomiting.

\section{DISCUSSION AND CONCLUSION}

The screening of literature available on Murraya koenigii, a leafy medicinal as well as a green leafy aromatic plant that belongs to family Rutaceae, possesses the fact that it is a popular remedy among diversified groups for various ailments. Curry leaves are generally used as a spice or seasoning in south Indian recipes wherein the whole leaf is 
used as such, which generally is discarded and not eaten. Hence, the nutritional potential of curry leaves remain underutilized. The present review also opens new pleasing view for discovery of cost effective and safe bioactive molecules from Murraya koenigii as this plant contains many phytochemical constituents and also a rich source of nutrients, minerals and vitamins which is beneficial for a treat and cure several diseases or disorders. The present review also shows that the bioactive molecules extracted from different parts of this plant possess various pharmacological activities such as activity on Antidiabetic, cholesterol-reducing property, antimicrobial activity, antiulcer activity, Antioxidative property, anti-diarrhea activity, anti-cancer activity, anti-inflammatory activity with much other phagocytic activity. also this Herbal medicines are more convenient and cheaper than other system of medicines. Therefore, this review article possess a great potential for effective treatment by herbal medicines as has given valuable information for development of newer herbal formulation. The available literature and wide spread availability of Murraya koenigii in Nepal and other south Indian countries make it an attractive plant resource for preclinical, clinical trials and formulations development in future research.

\section{REFERENCES}

Acharya, R., \& Acharya, K.P., (2009). Ethnobotanical study of medicinal plants used by Tharu community of Parroha VDC, Rupandehi district, Nepal. Scientific World, 9, 81-85.

Chowdhury, B. K. \& Chakraborty, D. B., (1969). Taxonomy XVIII. Mukoeic Acid-first carbazole carboxylic acid from plant sources. Chem Ind. (London), 17, 549.

Dasgupta, T., Rao, A. R., \& Yadava, P. K., (2003). Chemomodulatory action of curry leaf (Murraya koenigii) extract on hepatic and extrahepatic xenobiotic-metabolizing enzymes, antioxidant levels, lipid peroxidation, skin, and forestomachpapillomagenesis. Nutrition Research, 23,1427.

Dhami, N., (2008). Ethnomedicinal uses of plants in the western Terai of Nepal: A case study of Dekhatbhuli VDC of Kanchanpur district. In Jha, P.K., S.B.Karmacharya, M.K.Chhetry, C.B.Thapa, and B.B.Shrestha (eds). Medicinal Plants in Nepal: An Anthology of Contemporary Research. Ecological Society of Nepal (ECOS), Kathmandu, pp-165-177.

Ekor, M., (2013). The growing use of herbal medicines: issues relating to adverse reactions and challenges in monitoring safety. Front Pharmacol, 4, 177. Doi:10.3389/fphar.2013.00177.

Fiebig, M., Pezzuto, J. M., \& Soejarto, D. D., (1985). Part-40 Koenoline a further cytotoxic carbazole alkaloid from Murraya koenigii. Phytochemistry, 24(12), 3041-3043. 
Goutam, M.P., \& Purohit, R.M. (1974). Antimicrobial activity of essential oil of the leaves of Murraya koenigii. Indian J.Pharm.36, 11.

Kishore, N., Dubey, N.K., Tripathi, R.D., \& Singh, S.K. (1982). Fungitoxic activity of leaves of some higher plants. Natl. Acad.Sci.Lett., 5(1), 9.

Paudel, N., Aryal, M. R., Das, B. D., Adhikari, D. C., Rai, P. D., \& Shrestha, R., (2018). Some medicinal plants from Kathmandu Valley, Central Nepal. Int J Sci Rep., 4(4), 78-81.

Prajapati, N. D., Purohit, S. S., Sharma, A. K., \& Kumar, T. A., (2003). Handbook of Medicinal plants. Jodhpur: Agrobios, 352-353.

Press, J.R., Shrestha, K.K., \& Sutton, D.A. (2000). Annotated Checklist of the Flowering Plants of Nepal. The Natural History Museum, London.

Saini, S. C., \& Reddy, G. B. S., (2015). A review on curry leaves (Murraya koenigii): versatile Multi-potential Medicinal Plant. American J Phytomed clinical therapeutics, 3(4), 363368.

Shaikh, H., Shaikh, S., \& Rao, P., (2020). A review on Indian Traditional herb Murraya koenigii its nutritive and medicinal properties in Human health management. W JPR 9(6), 850-863. doi. 10.20959/wjpr.20206-176(3).

Singh, A. G., Panthi MP, and Tewari DD (2012). Wild plants used as vegetable in Rupandehi district of Nepal and their ethnomedicinal importance. J. Nat. Hist. Mus., 6, 111-125.

Singh, S., (2014). Ethnobotanical study of wild plants of Parsa district, Nepal. Ecoprint 24, 1-12. doi. http//dx.doi.org/10.3126/eco.v24i0.20641.

Singh, A. G., (2015). Survey of some medicinally important leafy vegetables in Rupandehi district of Western Nepal. Int J Appl Sci Biotechnol, 3(1), 111-118. doi:10.3126/ijasbt.v3i1.12220.

Srinivasan, K., (2005). Plant foods in the management of diabetes mellitus, spices as beneficial antidiabetic food adjuncts. Int J Food Sci Nutr, 56(6), 399-414.

Tiwari, S. \& Talreja, S. (2020). A Pharmaceutical importance of Murraya koenigii- A Complete Study. Ind. J.Pub.Health Research \& Dev., 11(11), 275-284.

Uprety, Y., Boon, E. K., Poudel, R. C., Shrestha, K. K., Rajbhandary, S., Ahenkan, A., \& Tiwari, N. N., (2010). Non-timber forest products in Bardiya district of Nepal: Indigenous use; trade, and conservation. J Hum. Eco.30 (3), 143-158. 